\title{
PENGARUH LOYALITAS KONSUMEN TERHADAP KEPUTUSAN PEMBELIAN RUMAH PADA PT.PANGRIPTA CONS MEDAN
}

\author{
Jerry Wibowo, Cece, Edi Winata \\ Alumni Sekolah Tinggi Ilmu Manajemen Sukma \\ Program studi Manajemen, Sekolah Tinggi Ilmu Manajemen \\ cecestim@gmail.com, ediwinatarivail1960@gmail.com
}

\begin{abstract}
The research aim is to know whether there is influence of consumer loyalty to decision of house purchase at PT.Pangripta Cons Medan.Sampel Company of this research is all property company registered in REI (Real Estate Indonesia) for year 2015 until 2016, Sampling using appliance sampling is the determination of the sample based on the wishes of researchers. Data analysis using Multiple Regression test with model accuracy (classic assumption test), hypothesis test using coefficient of determination test (R2), pasrial test (t test), while data processing using SPSS.
\end{abstract}

Keywords: Consumer loyalty and purchase decision.

\section{PENDAHULUAN}

Dalam persaingan bisnis antar perusahaan sangatlah ketat baik perusahaan yang bergerak di bidang barang maupun jasa, perusahaan yang ingin tetap unggul harus dapat memberikan produk atau jasa yang bekualitas dengan harga yang lebih murah, penyerahan lebih cepat dan pelayanan yang lebih baik, hal ini disebabkan karena adanya persaingan yang semakin kompetitif dengan perusahaan pesaing lainnya. Salah satunya adalah usaha jasa property, perkembangan teknologi dan arus informasi membuat konsumen menuntut lebih atas sebuah produk dan jasa. Tujuan utama untuk mencapai loyalitas konsumen dikarenakan hal ini sangat menguntungkan bagi perusahaan. Pemasar pada umumnya menginginkan bahwa konsumen yang diciptakannya dapat dipertahankan selamanya. Ini bukan tugas yang mudah mengingat perubahan-perubahan dapat terjadi setiap saat, baik perubahan pada diri konsumen, seperti selera maupun aspek-aspek psikologis serta perubahan kondisi lingkungan yang mempengaruhi aspek-aspek psikologis, sosial dan kultural konsumen.

Penelitian terdahulu yang dilakukan oleh Qalbi (2013) tentang analisis loyalitas pelanggan terhadap keputusan pembelian pada PT. Sinar Bintang Selatan Makasar, menunjukkan bahwa hasil penelitian loyalitas pelanggan berpengaruh positif dan signifikan terhadap antara ketiga variabel dengan keputusan pembelian, yakni sebesar 90,90\%, sedangkan sisanya sebesar 9,10\% merupakan faktor lain diluar dari harga dan kualitas pelayanan dan variabel yang paling dominan mempengaruhi keputusan pembelian adalah kualitas produk, alasannya karena kualitas produk memiliki nilai standardized coefficient yang lebih besar jika dibandingkan dengan variabel lainnya.

\section{Perumusan Masalah}

Melihat latar belakang masalah yang telah diuraikan di atas maka penulis merumuskan masalah sebagai berikut :

"Apakah ada pengaruh loyalitas konsumen terhadap keputusan pembelian rumah pada PT.Pangripta Cons Medan?”. 


\section{Batasan Masalah}

Untuk memperjelas arah penelitian ini dibatasi hanya pada loyalitas konsumen terhadap keputusan pembelian rumah PT.Pangripta Cons Medan saja.

\section{Tujuan Penelitian}

Tujuan dari penelitian ini adalah untuk mengetahui apakah ada pengaruh loyalitas konsumen terhadap keputusan pembelian rumah terhadap PT.Pangripta Cons Medan.

\section{METODE PENELITIAN}

\section{Tempat dan Waktu Penelitian}

Penelitian ini dilaksanakan di PT.Pangripta Cons yang beralamat di jalan Abdullah Lubis No.12A Medan. Penulis Melakukan Penelitian dari bulan April sampai dengan agustus 2015.

\section{Jenis Dan Sumber Data}

Sumber data yang digunakan dalam penelitian ini adalah :

1. Data Primer

2. Data Sekunder.

\section{Metode Pengumpulan Data}

Dalam proses pengumpulan data, metode yang digunakan penulis untuk mengumpulkan data-data yang dibutuhkan adalah melalui observasi (pengamatan) dan interview (wawancara) secara langsung dengan responden serta dengan menyebarkan kuesioner kepada sejumlah Konsumen yang menjadi responden dalam penelitian ini.

\section{Definisi Operasional}

1. Loyalitas konsumen (variabel independen) adalah variabel yang mempengaruhi terikat, yang terdiri dari net profit margin $\mathrm{X}$.

2. Keputusan pembelian (variable dependen) adalah variable yang mempengaruhi oleh variable bebas yaitu keputusan pembelian $(\mathrm{Y})$.

Tabel 1. Definisi Operasional dan Pengukuran Variabel

\begin{tabular}{|c|c|c|c|}
\hline Variabel & Definisi & Indikator & Skala \\
\hline $\begin{array}{l}\text { Loyalitas } \\
\text { Kosumen (X) }\end{array}$ & $\begin{array}{l}\text { Loyalitas adalah kesetiaan dari } \\
\text { seorang konsumen atau } \\
\text { Pembeli untuk tetap } \\
\text { menggunakan dan melakukan } \\
\text { pembelian ulang pada suatu } \\
\text { produk. }\end{array}$ & $\begin{array}{l}\text {-. Pembelian Ulang } \\
\text {-. Referensi }\end{array}$ & skala likert \\
\hline $\begin{array}{l}\text { Keputusan } \\
\text { Pembelian } \\
\text { (Y) }\end{array}$ & $\begin{array}{l}\text { Keputusan pembelian adalah } \\
\text { merupakan proses pemecahan } \\
\text { masalah konsumen atau } \\
\text { Pembeli yang melibatkan } \\
\text { pilihan antara dua atau lebih } \\
\text { alternatif tindakan atau } \\
\text { perilaku yaitu pilihan merek } \\
\text { mana yang akan dibeli. }\end{array}$ & $\begin{array}{l}\text {-. Kualitas Produk } \\
\text {-. Harga }\end{array}$ & skala likert \\
\hline
\end{tabular}


Metode Analisis Data

Untuk menguji sampai sejauh mana kebenaran hipotesis yang telah dikemukakan, maka metode analisis yang digunakan dalam pembahasan ini adalah :

1. Analisis Regresi Linear Sederhana

Metode analisis analisis regresi linear sederhana yaitu untuk menguji hipotesis, karena penelitian ini menggunakan lebih dari satu variabel bebas dengan model pesamaan:

$\mathrm{Y}=\mathrm{a}+\mathrm{bX}+\mathrm{e}$

$\mathrm{Y}=$ Keputusan Pembelian

$\mathrm{X}=$ Loyalitas Konsumen

$\mathrm{a}=$ Konstanta

$\mathrm{b}=$ Koefisien regresi Variable pemanfaatan internet sebagai sumber belajar.

$\mathrm{e}=$ error of tern (Variable yang tidak diteliti)

\section{Uji Validitas Dan Reliabilitas}

1. Uji Validitas

Uji validitas adalah ketepatan atau kecermatan suatu instrument dalam mengukur apa yang diukur. Uji validitas sering digunakan untuk mengukur ketepatan suatu item dalam kuesioner atau skala apakah item-item pada kuesioner tersebut sudah tepat dalam mengukur apa yang ingin diukur. Penelitian langsung terhadap koefisien korelasi bisa digunakan maksimal korelasi di atas dari 0,30.

2. Uji reliabilitas

Uji Reliabilitas merupakan pengujian yang menunjukkan sejauh mana stabilitas dan konsistensi dari alat ukur yang kita gunakan, sehingga memberikan hasil yang relatif konsisten jika pengukuran tersebut diulangi.

\section{Kerangka Berfikir}

Terciptanya Loyalitas konsumen merupakan tujuan dari suatu bisnis. untuk menciptakan para pelanggan merasa puas sehingga Terciptanya loyalitas dapat memberikan beberapa manfaat, diantaranya hubungan antara perusahaan dengan pelanggannya menjadi harmonis sehingga memberikan dasar yang baik bagi pembelian ulang dan terciptanya kesetiaan terhadap merek serta membuat suatu rekomendasi dari mulut ke mulut (word of mouth) yang menguntungkan bagi perusahaan.

Berdasarkan uraian di atas maka kerangka berpikir dalam penelitian ini dapat dilihat pada Gambar 1.

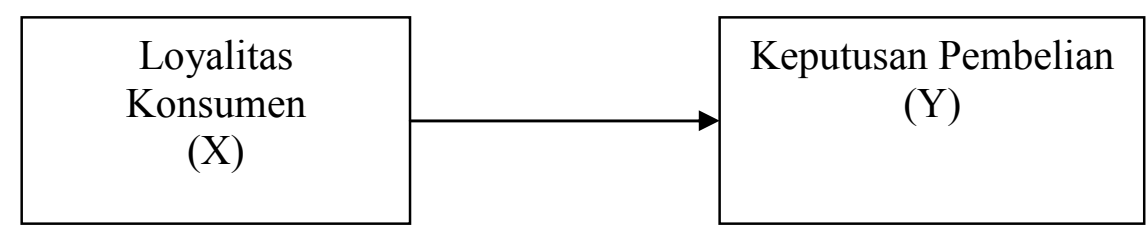

Gambar 1. Kerangka Berpikir

\section{Hipotesis}

Hipotesis adalah suatu jawaban yang bersifat sementara terhadap permasalah penelitian, sampai terbukti melalui data yanng terkumpul". (Arikunto, 2010: 110). Formulasi hipotesis peneletian ini adalah Jika $t_{\text {hitung }} \leq t_{\text {tabel }}$ maka $\mathrm{H}_{0}$ diterima, $\mathrm{H}_{1}$ ditolak, artinya secara parsial loyalitas konsumen tidak berpengaruh terhadap keputusan 
pembelian rumah pada PT.Pangripta Cons Medan, sedangkan jika $t_{\text {hitung }}>t_{\text {tabel }}$ maka $\mathrm{H}_{0}$ ditolak, $\mathrm{H}_{1}$ diterima, artinya secara parsial loyalitas konsumen berpengaruh terhadap keputusan pembelian rumah pada PT.Pangripta cons Medan.

Berdasarkan formulasi diatas, maka hipotesis penelitian adalah "loyalitas konsumen berpengaruh positif dan signifikan tehadap keputusan pembelian rumah pada PT.Pangripta Cons medan”.

\section{Pengujian Hipotesis}

Pengujian hipotesis pada penelitian ini berupa langkah pembuktian dengan penelitian atau hipotesis. Lagkah ini menguji kebenaran hipotesis yang dikemukakan peneliti secara linier. Penguji hipotesis yang dilaksanakan penelitian sebagai berikut :

\section{Koefisien determinasi $\left(\mathbf{R}^{2}\right)$}

Pada dasarnya mengukur seberapa besar kemampuan model dalam menerangkan variabel terikat. Semakin besar nilai koefisien determinasi (Mendekati Satu), maka dapat dikatakan bahwa pengaruh variabel bebas (X) dan (Y). Koefisiensi determinasi dari hasil regresi sederhana menunjukkan tingkat kejelasan yang dapat diberikan oleh variabel loyalitas terhadap variabel keputusan membeli.

\section{Uji Parsial (Uji t)}

Uji parsial (uji t) bertujuan untuk melihat pengaruh loyalitas konsumen secara parsial terhadap pengambilan keputusan pembelian rumah dengan kriteria sebagai berikut :

a. Jika $t_{\text {hitung }} \leq t_{\text {tabel }}$ maka $\mathrm{H}_{0}$ diterima, $\mathrm{H}_{1}$ ditolak, artinya secara parsial penelitian tidak ada pengaruh.

b. Jika $t_{\text {hitung }}>t_{\text {tabel }}$ maka $\mathrm{H}_{0}$ ditolak, $\mathrm{H}_{1}$ diterima, artinya secara parsial penelitian terdapat pengaru

\section{HASIL PENELITIAN DAN PEMBAHASAN}

\section{Hasil Penelitian}

\section{Uji Validitas}

Tabel 1. Uji Validitas

\begin{tabular}{|c|c|c|c|c|}
\hline Variabel & $\begin{array}{l}\text { Item } \\
\text { Pertanyaan }\end{array}$ & Korelasi & $\begin{array}{l}\text { Standar } \\
\text { Korelasi }\end{array}$ & Keterangan \\
\hline \multirow{6}{*}{ 1. Pengaruh Loyalitas } & $\mathrm{X} 1$ & ,637 & 0,361 & Valid \\
\hline & $\mathrm{X} 2$ &, 711 & 0,361 & Valid \\
\hline & $\mathrm{X} 3$ & 473 & 0,361 & Valid \\
\hline & $\mathrm{X} 4$ & 657 & 0,361 & Valid \\
\hline & X5 & 687 & 0,361 & Valid \\
\hline & X6 & 678 & 0,361 & Valid \\
\hline \multirow[t]{7}{*}{ 2. Keputusan Pembelian } & Y1 & ,662 & 0,361 & Valid \\
\hline & Y2 &, 862 & 0,361 & Valid \\
\hline & Y3 &, 794 & 0,361 & Valid \\
\hline & Y4 & 903 & 0,361 & Valid \\
\hline & Y5 & ,899 & 0,361 & Valid \\
\hline & Y6 &, 892 & 0,361 & Valid \\
\hline & Y7 & ,805 & 0,361 & Valid \\
\hline
\end{tabular}

Sumber : Lampiran SPSS

Berdasarkan tabel 5.6 yakni hasil uji validitas, untuk variabel loyalitas konsumen dengan 6 item pertanyaan ternyata semua item pertanyaan sah (valid) sebab memiliki 
nilai korelasi di atas 0,361 , sedangkan variabel keputusan pembelian dengan 7 item pertanyaan di mana memiliki kisaran korelasi di atas 0,361. Berarti semua item pertanyaan yang akan dimasukkan dalam analisis regresi dapat dikatakan sah/valid sebab memiliki kisaran korelasi di atas dari 0,361.

\section{Uji Reliabilitas}

Tabel 2. Hasil Uji Reliabilitas

\begin{tabular}{|l|l|l|l|l|}
\hline No. & $\begin{array}{l}\text { Variabel } \\
\text { Penelitian }\end{array}$ & $\begin{array}{l}\text { Cronbach's } \\
\text { Alpha }\end{array}$ & $\begin{array}{l}\text { Standar } \\
\text { Cronbach's } \\
\text { Alpha }\end{array}$ & Keterangan \\
\hline 1. & Kualitas produk &, 850 & 0,60 & Reliabel \\
2. & Keputusan pembelian &, 945 & 0,60 & Reliabel \\
\hline
\end{tabular}

Sumber : Lampiran SPSS 17

Menurut Dwi (2000 : 97) bahwa reliabilitas yang kurang dari 0,60 adalah kurang baik, sedangkan 0,70 dapat diterima dan di atas 0,80 adalah baik. Sehingga dari kedua variabel penelitian yang akan digunakan dalam pengujian ternyata semua variabel penelitian memiliki cronbach's alpha yang di atas 0,80 . Dengan demikian maka dapatlah disimpulkan bahwa semua item pertanyaan dapat dikatakan andal (reliabel) sebab memiliki nilai cronbach's alpha $>0,60$.

\section{Pengujian Hipotesis}

\section{a. Koefisien Determinasi $\left(\mathbf{R}^{2}\right)$}

Koefisien determinasi dilakukan untuk melihat tingkat kemampuan variabel bebas menjelaskan variabel terikat. Untuk melihat tingkat kemampuan variabel bebas dan variabel terikat dapat dilihat dari tabel berikut ini:

Tabel 3. Model Summary

\begin{tabular}{|l|l|l|l|l|}
\hline Model & $\mathrm{R}$ & R Square & $\begin{array}{l}\text { Adjusted R } \\
\text { Square }\end{array}$ & $\begin{array}{l}\text { Std. Error of } \\
\text { Estimate }\end{array}$ \\
\hline 1 & $.896^{\mathrm{a}}$ & .802 & .798 & 2.57674 \\
\hline
\end{tabular}

a. Predictors : (Constant), loyalitas Konsumen

b. Dependent Variabel : Keputusan_Pembelian

Berdasarkan pada tabel diketahui bahwa nilai $\mathrm{R}^{2}$ adalah sebesar .802 atau $80,2 \%$ ini mengartikan bahwa kemampuan dari loyalitas Konsumen dalam menjelaskan Keputusan Pembelian adalah sebasar $80,2 \%$ sedangkan sisanya sebesar $19,8 \%$ dijelaskan oleh variabel lainnya yang tidak dimasukkan ke dalam model penelitian ini.

\section{b. Uji Parsial (Uji t)}

Tabel 4. Uji t

Coefficients $^{\mathrm{a}}$

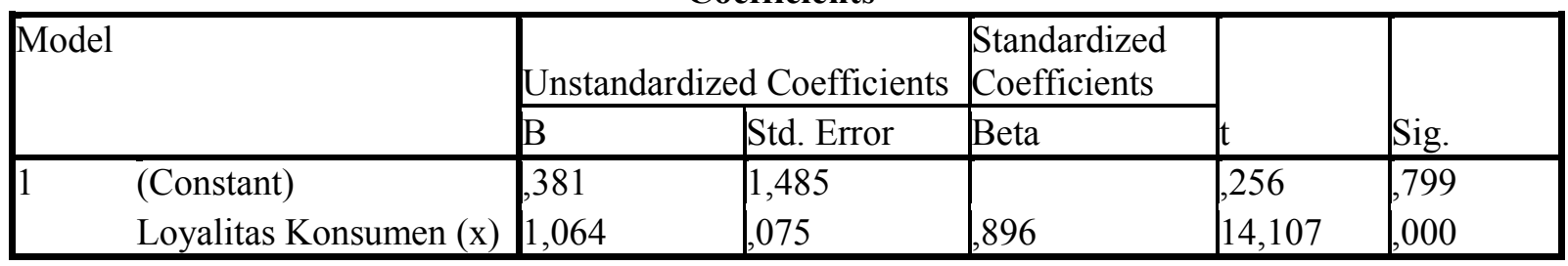

a. Dependent Variable: Keputusan Pembelian (y)

Berdasarkan hasil persamaan diperoleh nilai $t_{\text {hitung }}>t_{\text {tabel }}(14,107>2.00958)$ maka $\mathrm{H}_{0}$ ditolak, $\mathrm{H}_{1}$ diterima, artinya secara parsial loyalitas konsumen berpengaruh positif dan signifikann terhadap keputusam pembelian pada PT.Pangripta Cons Medan. 


\section{Pembahasan}

Hasil pengujian hipotesis pertama menunjukan bahwa Loyalitas konsumen berpengaruh signifikan terhadap keputusan pembelian. Hal ini ditujukan dengan nilai signifikan keputusan pembelian dibandingkan dengan nilai alpha penelitian. Besarnya pengaruh loyalitas konsumen terhadap keputusan pembelian adalah $80,2 \%$ sedangkan sisanya sebesar 19,8\%, dijelaskan oleh faktor-faktor lain yang termasuk termasuk dalam penelitian ini, misalnya Harga dan Brand/Merk.

Hasil pengujian hipotesis kedua diperoleh nilai $t_{\text {hitung }}>t_{\text {tabel }}(14,107>2.00758)$ maka $\mathrm{H}_{0}$ ditolak, $\mathrm{H}_{1}$ diterima, artinya secara parsial loyalitas konsumen berpengaruh positif dan signifikann terhadap keputusam pembelian pada PT.Pangripta Cons Medan.

Dengan hasil ini, memberikan gambaran bahwa loyalitas konsumen yang diciptakan oleh perusahaan sangat menentukan konsumen membeli produknya kembali. Produknya harus memenuhi harapan yang di inginkan konsumen atau calon pembeli agar konsumen mau membelinya. Oleh karna itu perusahaan harus benar-benar memperhatikan setiap rumah yang akan dibangunnya, misalnya perbandingan semen dan pasir, kualitas kusen dan kayu serta kulitas keramiknya dan lain sebagainya.

Hasil penelitian yang dilakukan oleh Qalbi (2013) tentang analisis loyalitas pelanggan terhadap keputusan pembelian. Hasil penelitian menunjukan bahwa terdapat pengaruh positif dan signifikan antara loyalitas konsumen terhadap keputusan pembelian pada PT. Sinar Bintang Selatan.

\section{KESIMPULAN}

Adapun kesimpulan yang dapat diberikan sehubungan dengan hasil penelitian ini dapat diuraikan sebagai berikut:

1. Hasil analisis uji regresi antara factor loyalitas konsumen dengan keputusan pembelian ternyata ditemukan ada pengaruh positif dan signifikan antara kedua variable yakni sebesar $80,2 \%$ sedangkan sisanya sebesar $19,8 \%$.

2. Variabel yang paling dominan mempengaruhi keputusan pembelian adalah kualitas produk, alasannya karena kualitas produk memiliki nilai standardized coefficient yang lebih besar jika dibandingkan dengan variable lainnya. 


\section{REFERENCES}

Cece. (2003). Analisis Hubungan Perencanaan Strategi Aliansi PDAM Tirtanadi-PT. Telekominikasi Divre I Terhadap Peningkatan Kualitas Pelayanan Pelanggan PDAM Tirtanadi... Universitas Sumatera Utara.

Daryanto.(2013). Sari Kuliah Manajemen Pemasaran (II). Bandung: PT. Sarana Tutorial Nurani Sejahtera.

Dewi, S. P., \& Hidayat, R. (2014). Pengaruh Net Profit Margin dan Return on Assets terhadap Harga Saham pada Perusahaan Otomotif yang terdaftar di Bursa Efek Indonesia. Jurnal Ilman, 1(1), 1-10.

Dinamika, S. G., \& Siregar, E. B. A. (2016). Developing English Syllabus for Tourism Management Students. In Proceedings of the Fourth International Seminar on English Language and Teaching (ISELT-4) (Vol. 13, pp. 16-17).

Fandy Tjiptono, 2012, 10 Prinsip Kepuasan Pelanggan, cetakan kelima, Elex Media Komputindo, Jakarta

Fathimah, V. (2017). Pengaruh Perkembangan Jumlah Tabungan, Deposito dan Bagi Hasil terhadap Jumlah Pembiayaan yang Diberikan oleh Perbankan Syariah di Sumatera Utara. Jurnal Ilman, 5(1), 41-52.

Hasan, 2011, Marketing, cetakan pertama, Penerbit : Medpress, Yogyakarta.

Hidayat, R. (2010). Analisis Tingkat Penggunaan Internet Dikalangan Mahasiswa dan Hubungannya dalam Peningkatan Nilai Akademik (Studi Kasus pada Mahasiswa di Kota Medan). Jurnal Mediasi, 2(2), 55-63.

Hidayat, R. (2015). Performance Appraisal sebagai Alat Pengukuran Kepuasan Kerja Karyawan. Jurnal Ilman, 3(1), 1-8.

Keller, K. L., \& Kotler, P. (2012).Marketing Management (14th ed.). New Jersey: Pearson Prestice Hall.

Kotler dan Keller, 2012, Manajemen Pemasaran, edisi tigabelas, cetakan pertama, Penerbit : BPFE, Yogyakarta

Kotler, P. (2012). Manajemen Pemasaran Persfektif Asia (Pertama). Yogyakarta: Andi.

Kotler, P., \& Amstrong, G. (2012).Prinsip-Prinsip Pemasaran (13th ed.). Jakarta: Erlangga.

Morisan, 2010, Keputusan Pembelian, Penerbit : Gramedia Pustaka Utama, Jakarta.

Nasution, W. A. (2009). Pengaruh kepuasan kerja karyawan terhadap intensi turnover pada call center Telkomsel di Medan. Jurnal Mandiri, 4(1), 1-11.

Ningratri, Y. A. (2017). Analisis Pengaruh Strategi Bauran Pemasaran Jasa (3P) terhadap Keputusan Mahasiswa Memilih STIM Sukma Medan. Riset \& Ejurnal Manajemen Informatika, 3(1), 50-56.

Novianti, R., Iskandar, \& Adawiyah, R. (2015).Pengaruh Kualitas Produk dan Pelayanan Terhadap Kepuasan Konsumen Pada Depo Air Minum Isi Ulang Water Jaya di Tenggarong.JEMI, 15(1), 27-34.

Prana, R. R. (2016). Analisis Faktor-faktor yang Mempengaruhi Pendapatan Asli Daerah (PAD) Kota Tebing Tinggi. Jurnal Ilman, 4(1), 74-86.

Prasastono, N., \& Pradapa, S. Y. F. (2012).Kualitas Produk dan Kulaitas Pelayanan Terhadap Kepuasan Konsumen Kentucky Fried Checken Semarang Candi.Dinamika Kepariwisataan, XI(2), 13-23.

Saidani, B., \& Arifin, S. (2012). Pengaruh kualitas produk dan kualitas layanan terhadap kepuasan konsumen dan minat beli pada ranch market, 3(1), 1-22. 
Setiadi, 2010, Bauran Pemasaran, cetakan pertama, Penerbit : Alfabeta, Bandung

Sinuhaji, E. (2010). PENERAPAN LAYANAN UNGGUL DALAM PEMASARAN PRODUK BANK. Jurnal Mediasi, 2(1).

Subagyo, 2010, loyalitas Konsumen, edisi sepuluh, cetakan pertama, Penerbit : Graha Ilmu, Yogyakarta

Sugiyono.(2012). Metode Penelitian Bisnis (Pendekatan Kuantitatif, Kualitatif dan $R \& D)$. Bandung: Alfabeta.

Sukendro, H. A. (2012). Pengaruh Citra Merek dan Kualitas Pelayanan terhadap Kepuasan Jama'ah pada Kelompok Bimbingan Ibadah Haji (KBIH) Indosat Medan. Universitas Terbuka.

Swanta, 2012, Manajemen Pemasaran Jasa, cetakan pertama, edisi kedua, Penerbit : Salemba Empat, Jakarta

Tjiptono, F. (2012).Service Manajemen Mewujudkan Pelayanan Prima. Yogyakarta: CV. Andi Offset.

Wardayani. (2013). Pengaruh Pengetahuan Dewan Tentang Anggaran, Partisipasi Masyarakat dan Transparansi Kebijakan Publik terhadap Kinerja DPRD dalam Pengawasan Keua. Jurnal BIS-A Politeknik LP3i Medan, 2, 35-45.

Widjanarko, B. (2015). PENGARUH PEMERIAN KOMPENSASI DAN KOMUNIKASI TERHADAP SEMANGAT KERJA KARYAWAN PADA BUMI KARYA TAMA INSURANCE CABANG MEDAN. Jurnal Research Sains, 1(2), $130-152$.

Winata, E. (2015). Pengaruh Disiplin Kerja dan Budaya Kerja terhadap Semangat Kerja Karyawan pada PT. Mayasari Binangun Medan. Research Sains, 1(2), 100-117.

Zeithml,\& Bitner. (2012). The Concept of Customer Satisfaction. USA: The McGraw Hill-Companies.

Zuhri, \& Pertiwi, L. S. (2016). Airline revenue management under number of no-shows uncertainty. Global Journal of Pure and Applied Mathematics, 12(1), 1003-1012. 